\title{
高精度温度流速計の開発*
}

渡部 英昭 ${ }^{* 1}$, 蒔田 秀治 ${ }^{* 2}$, 田子 真 ${ }^{* 3}$

\section{Development of High Precision Thermo-Anemometer}

\author{
Hideaki WATANABE $^{* 1}$, Hideharu MAKITA and Makoto TAGO \\ ${ }^{* 1}$ Akita National College of Technology, Dept. of Mechanical Engineering \\ Bunkyo-chou, Akita, Akita, 011-8511 Japan
}

An improved system of thermo-anemometer was developed. Temperature compensator was designed based on more accurate equations. Assumptions in the temperature compensation equation were minimized to make minute adjustment in each part of the circuit. An improved corrector circuit reduced the error of the velocity signal to be less than $\pm 1 \%$ up to about $120^{\circ} \mathrm{C}$. A new digital delay device was designed. Deviations from the specification of delay device could be adjusted by employing an automatic amplitude and mean voltage adjuster. Consequently, it can regenerate the original velocity waveform quite accurately, free from wave deformation and electrical noise up to $6 \mathrm{kHz}$. Calibration time was reduced. The present device can obtain higher correlation terms in the thermal flow fields more accurately.

Key Words : Thermo-Anemometry, Velocimetry, Flow Measurements, Turbulence

\section{1. 緒言}

流れ場に存在する温度変動は密度差を生み, 局所的な浮力が鉛直方向に作用する. その影響の解明は, 熱流体機器の効率 向上や污染物質の大気拡散予測などの気象・環境現象のメカニズムを解明するために重要である.

通常の定温度型熱線流速計は，原理上，温度場と速度場が共存する流れ場を計測できない. これまで温度と速度を分離計 測する方法が提案されてきたが(1) (7) , 種々の問題を内包していた.

蒔田ら ${ }^{(8)} \sim{ }^{(9)}$ は新しい 温度補償式を提案し, 温度と速度を同時計測可能な二線式温度流速計を開発して，従来の方法が持 つ問題をほぼ解決した. しかしながら，1）補償式（1）中のパラメータの定数近似，2）温度信号の遅延に用いる遅延素子 の性能不足，などの問題がある. これらの久陥により，1）では高温領域での速度信号の減衰など補償精度の低下，各係数 設定時の煩雑さによる較正の長時間化，2）では高周波帯域での速度信号補償量の過不足や高周波ノイズ発生，などを若起 する.

本研究は，1）温度補償式の改良と補償回路の高精度化，2）任意の温度において補償係数を設定可能な回路の製作，3） 調整が容易で高周波帯域まで温度波形を復元可能な遅延回路及び温度補償回路の製作，などの改良を加え，高温気流中で高 周波領域まで高次相関量を正確かつ効率よく計測できる温度流速計の開発を目的とする.

\section{2. 従来の二線式温度流速計}

本研究も, 流速しに対寸る温度補償式は, 文献（8）に準拠し, 以下の式により求めた.

\footnotetext{
*原稿受付 2012 年 6 月 10 日

${ }^{* 1}$ 正員, 秋田工業高等専門学校（广011-8511 秋田県秋田市飯島文京町 1-1）

*2 正員, フェロー, 豊橋技術科学大学名誉教授

*3正員, 秋田大学 (T010-8502 秋田県秋田市手形学園町 1-1)

E-mail: watanabe@ipc.akita-nct.ac.jp
} 
$U=K_{C}\left\{\frac{\left(1+K_{B} \theta_{r}\right)+K_{B} \Delta \theta}{\left(1-K_{A} \theta_{r}\right)-K_{A} \Delta \theta} E^{2}-\left[\left(1+K_{B} \theta_{r}\right)+K_{B} \Delta \theta\right] K_{D}\right\}^{2.22}$

ここで, $K_{A}=1 / \theta_{W}, K_{B}=1 /\left(\theta_{W}+K_{3}\right), K_{C}=K_{1} A_{0} B_{0}, K_{D}=K_{2} / A_{0}$ であり，その他パラメータの詳細も文献（8）に拠る.

蒔田らのシステム ${ }^{(8)}$ は，(1)定温度型熱線流速計，(2)定電流型温度計，(3)温度プローブ用高周波・(4)低周波位相補償回路， （5)遅延補償回路，6温度補償用演算回路，から成る. 流速信号 $U$ を用いて(3)(4)5)において温度信号の各補償を行い，同時 に温度信号 $\theta_{a}$ を(6) に入力て式 (1) の\{\}内の温度補償式を演算する. $K_{D}, K_{C}$ は，流速計側のゼロ点とゲインとして決定 される.

本研究のシステムも基本的には同一である. ただし, 文献 (8) は $K_{B}=1 /\left(\theta_{W}+K_{3}\right)$ 中のパラメータ $K_{3}=718$ として定数近 似することにより，演算を簡単化し，補償回路と減算器，累乗器で式（1）の演算を行っている. しかし，次のような改良 すべき点がある. 1) 定数とした $K_{B}$ 中の $K_{3}$ は, ワイヤ温度 $\theta_{W}$ の関数である. 2) $K_{3}$ の定数化による演算誤差により， $\theta_{a}$ が大きな領域で精度が劣化する. 3）また $\theta_{W}$ の再設定時， $K_{A}, K_{B}$ を再度算出する. 4）較正時， $\theta_{a}$ を室温 $\theta_{r}$ まで戻す. 更 に，5）正確な補償が実現されない時は，全較正手順を繰り返す必要があり，調整時間が増す.

\section{3. 温度補償回路の改良}

より効率的で高精度の補償を行うためには，1） $K_{3} を ， \theta_{W}$ と $\theta_{r}$ の関数として導出し，その上で $K_{3}, K_{A} \theta_{a}, K_{B} \theta_{a}$ を自動

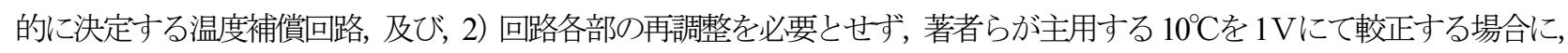
出力が回路電圧の上限を超えない範囲で補償可能な流速信号Uの温度補正回路の開発を行う必要がある.

\section{$3 \cdot 1 \quad K_{3}$ の導出}

$K_{3}=2 n / m^{(8)}$ に対し, 線径 $5 \mu \mathrm{m}$, 長さ $1 \mathrm{~mm}$ のタングステンワイヤに関して, $\theta_{r}=5{ }^{\circ} \mathrm{C}, 15{ }^{\circ} \mathrm{C}, 25{ }^{\circ} \mathrm{C}$ 時の各加熱 度 $\alpha_{W}$ での $\theta_{W}$ および $\theta_{W}=0^{\circ} \mathrm{C}$ における各物性值に基づき $K_{3}$ を算出し, 一次式 $K_{3}=P \times \theta_{W}+Q$ （図 1 ） で求めた $P$, $Q$ を表 1 に示寸.

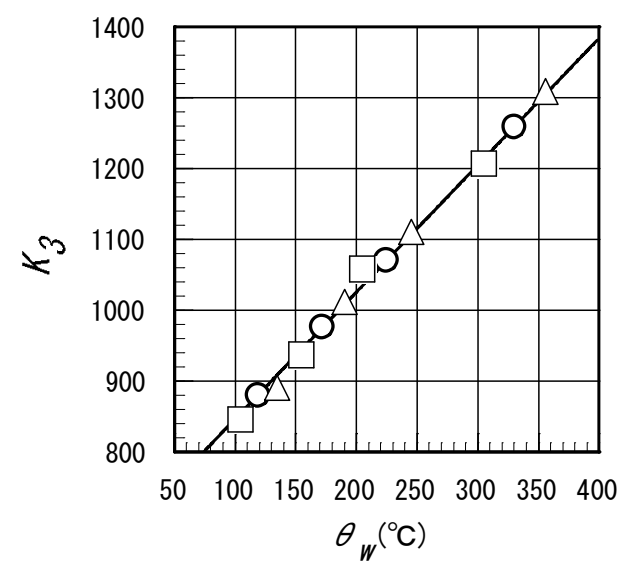

Fig. $1 \quad K_{3}$ vs $\theta_{W}$ of various $\theta_{r}$ at $\alpha_{W}=0.5$. $\left(\square: \theta_{r}=5^{\circ} \mathrm{C}, \bigcirc: \theta_{r}=15^{\circ} \mathrm{C}, \triangle: \theta_{r}=25^{\circ} \mathrm{C}\right)$

Table 1 The values of $P$ and $Q$ at different $\theta_{r}$ for $\alpha_{W}=0.5$.

\begin{tabular}{|c|c|c|}
\hline$\theta_{r}\left({ }^{\circ} \mathrm{C}\right)$ & $P$ & $Q$ \\
\hline 5 & 1.81 & 660 \\
\hline 15 & 1.792 & 663.2 \\
\hline 25 & 1.874 & 644.3 \\
\hline
\end{tabular}




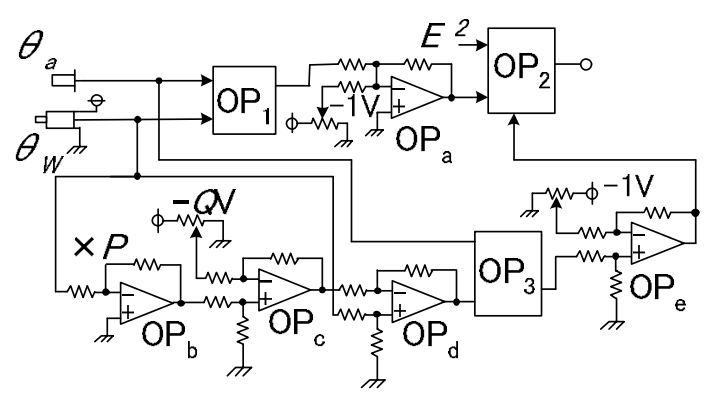

Fig. 2 Schematic of new compensator circuit for hot wire output.

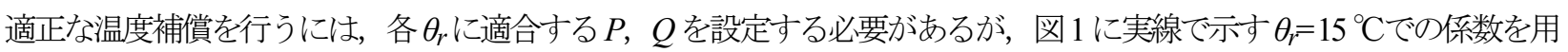
いると, $\theta_{r}$ 全領域で $K_{B}$ が誤差 $\pm 2 \%$ 以に収まり, 実際の較正時に $K_{C}$ と $K_{D}$ を微調整することにより, 温度, 速度とも許 容誤差 $\pm 0.5 \%$ 以内に設定可能である. $\alpha_{W}$ 設定後は $P, Q$ を $\theta_{r} \quad\left(5 \sim 25{ }^{\circ} \mathrm{C}\right)$ に独立な一定值とすると， $K_{3}$ は $\theta_{W}$ だけの関 数となる. $\theta_{W}$ は較正時の $\theta_{r}$ での泠抵抗 $R_{r}$ と $\alpha_{W}$ で定義され，

$$
\theta_{W}=\left(\alpha_{W} \times R_{r}\right) \times\left(R_{0} \times J\right)^{-1}
$$

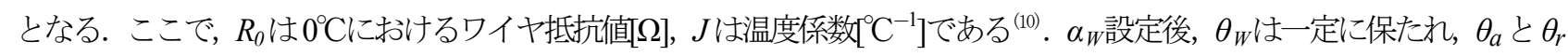
に独立となり， $\theta_{W}$ も $\alpha_{W}$ のみ関数となる.

式（1）を変形寸ると

$$
U=K_{C}\left\{\frac{\left(1+K_{B} \theta_{a}\right)}{\left(1-K_{A} \theta_{a}\right)} E^{2}-\left(1+K_{B} \theta_{a}\right) K_{D}\right\}^{2.22}
$$

式（3）に $\theta_{W}$ と $\theta_{a}$ を与えることで， 熱線出力 $E$ から Uの演算が可能となる.

式 (3) 中 \{\} 内第 1 項の演算回路を図 2 に示寸. 図中 $\theta_{a}$ は気流の温度信号, $\theta_{W}$ は補償回路で設定された一定值である. $\theta_{W}$ を入力し, $\mathrm{OP}_{\mathrm{b}}, \mathrm{OP}_{\mathrm{c}}$ でゲイン $P$ と $Q$ を設定すれば, $\mathrm{OP}_{\mathrm{d}}$ で $\theta_{W}+K_{3}$ が得られ $\mathrm{OP}_{3}, \mathrm{OP}_{\mathrm{e}}$ で $K_{B} \theta_{a}=\theta_{d} /\left(\theta_{W}+K_{3}\right)$ と $\left(1+K_{B} \theta_{a}\right)$ が計算される. 次に, $\mathrm{OP}_{1}$ と $\mathrm{OP}_{\mathrm{a}}$ で $K_{A} \theta_{a}=\theta_{a} / \theta_{W}$ と $\left(1-K_{A} \theta_{a}\right)$ を演算し, これらと直線化前の流速信号 $E^{2}$ との演算を $\mathrm{OP}_{2}$ で 行うことで, \{\} 内第 1 項が得られる. 以後の演算は, 蒔田ら ${ }^{(8)}$ と同様に行われるが, 本回路は, $\theta_{a}$ の入力だけで温度補償 可能となり, 再較正時に $\theta_{a}$ を $\theta_{r}$ に戻寸必要がなくなり, 較正時間を大幅に短縮することができる.

\section{$3 \cdot 2$ 高温での減衰に対する流速補正回路}

演算過程で各係数誤差や電子部品の個体差により, 特に $\theta_{a}$ が高い時に補償精度が劣化する. 本回路も, 全 $\theta_{a}$ で正確に温 度補償するためには，各パラメータを厳密に設定する必要がある.

$\theta_{r}=18{ }^{\circ} \mathrm{C}, \theta_{W}=270{ }^{\circ} \mathrm{C}$, 一様流速 $U_{\bar{\sigma}}=3,5,7 \mathrm{~m} / \mathrm{s}$ の加熱気流に対する温度補償の有無による比較を図 3 に示寸. 計測に は, 較正した熱電対温度計を使用した. 未補償平均流速 $U$ は $\theta_{a}$ の上昇と共に減衰しているが, 補償後の平均流速 $U_{C} は, \theta_{r}$ $\leqq \theta_{a} \leqq 65{ }^{\circ} \mathrm{C}$ で咸衰が $1 \%$ 末満に収まっている. しかし $\theta_{a}>65{ }^{\circ} \mathrm{C}\left(=\theta_{B}\right)$ では, 各 $U_{C}$ は减衰し始めている.

補正温度 $\theta_{R}=\theta_{a}-\theta_{B}$ に対して減衰領域での $U_{C} / U_{0}$ を求め, 図4 に実線で示寸. $\theta_{R}$ を用いて $U_{C}$ の減衰量を補正した平均流 速を $U_{R}$ とすると，各 $U_{0}$ とも $\theta_{R} \geqq 0$ でほぼ同じ 2 次曲線で近似できる. 設計段階でのシミュレーションにより

$$
U_{R}=\left(A \times \theta_{R}\right)^{2} \times U_{C}+B \times U_{C}
$$

で表される補正を行えば, 最も簡略な回路で $U_{d} U_{0}$ は厳密に $1 \mathrm{mV}$ オーダーまで 1.000 を保つことが分かった. よって式 (4) に基づき，流速 $U_{C}$ の補正回路（図5）を製作した. 


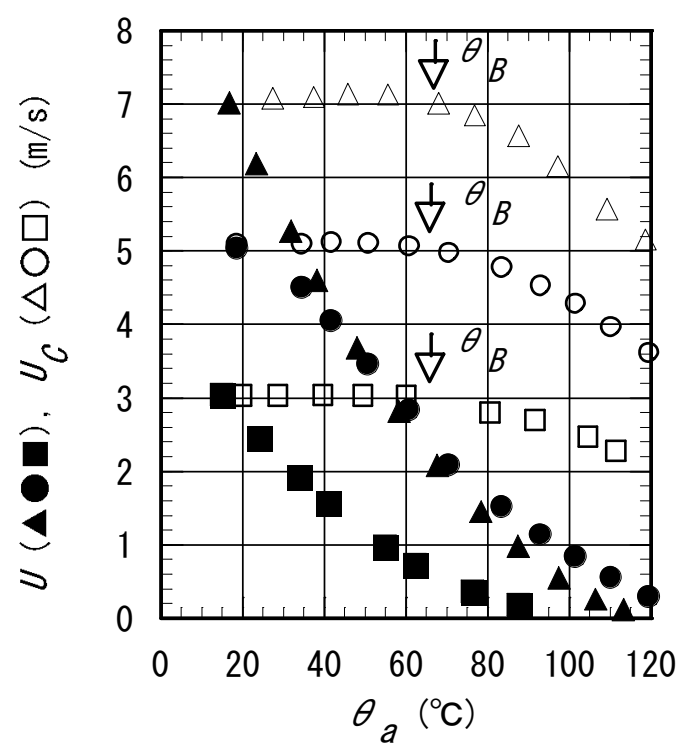

Fig. $3 U$ and $U_{C}$ decays increase with $\theta_{a}$.

$\left(\boldsymbol{\Lambda}, \triangle: U_{\bar{\sigma}}=7 \mathrm{~m} / \mathrm{s}, \quad\right.$ ○, $\left.\bigcirc: U_{\bar{\sigma}}=5 \mathrm{~m} / \mathrm{s}, \mathbf{\square}, \square: U_{\bar{\sigma}}=3 \mathrm{~m} / \mathrm{s}\right)$

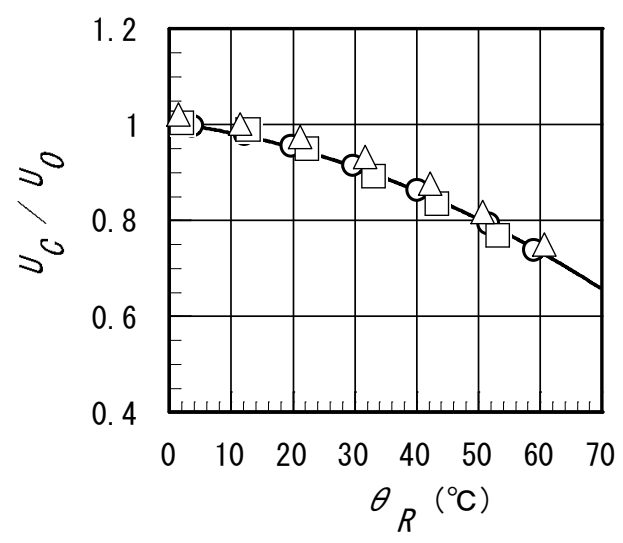

Fig.4 $U_{C} / U_{0}$ decays with increase in $\theta_{R}$, where $U_{C} / U_{\bar{\sigma}}=-A_{l} \theta_{R}{ }^{2}-B_{l} \theta_{R}+1.000 . \quad\left(\triangle: U_{\sigma}=7 \mathrm{~m} / \mathrm{s}, \quad \bigcirc: U_{\sigma}=5 \mathrm{~m} / \mathrm{s}, \square: U_{\sigma}=3 \mathrm{~m} / \mathrm{s}\right)$

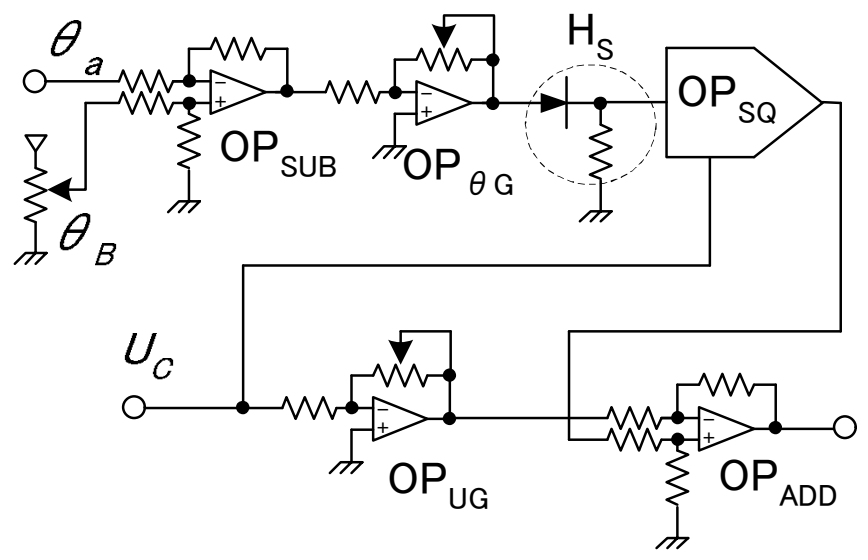

Fig.5 Schematic of corrector circuit for $U_{C}$. 


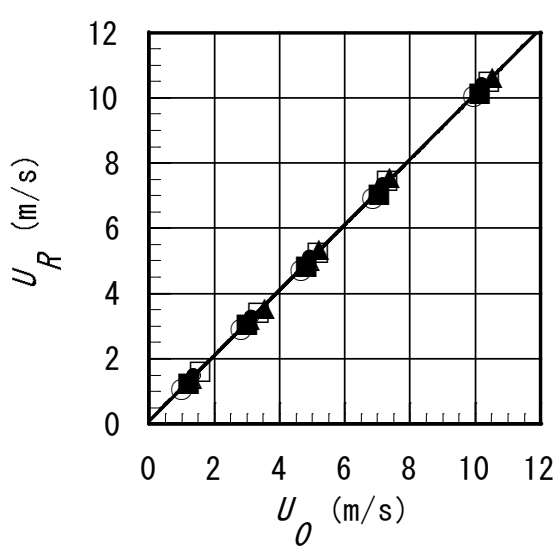

Fig.6 Static characteristics of corrector circuit.

: $\theta_{a}=\theta_{r}=30^{\circ} \mathrm{C}$

$: \theta_{a}=40^{\circ} \mathrm{C}, \triangle: \theta_{a}=60^{\circ} \mathrm{C}$,

$\theta_{a}=80^{\circ} \mathrm{C}, \quad \square: \theta_{a}=100^{\circ} \mathrm{C}$,

$\Delta: \theta_{a}=120^{\circ} \mathrm{C}$

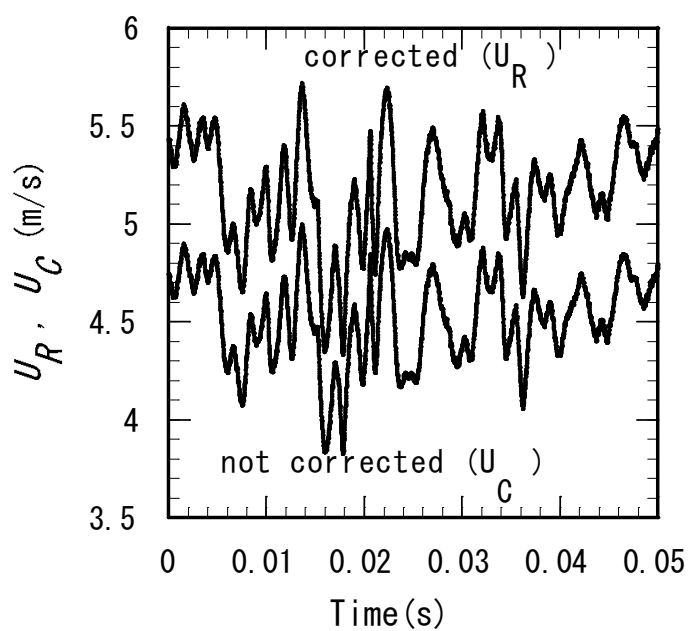

Fig.7 Comparison between waveforms of $U_{C}$ and $U_{R}$ in the wake of a heated and an unheated cylinder.

$$
\left(U_{0}=5.3 \mathrm{~m} / \mathrm{s}, x / d=7, y / d=5, \quad d=2 \mathrm{~mm}, \theta_{a}=100^{\circ} \mathrm{C}\right)
$$

$A, B, \theta_{B}$ 設定後, $\theta_{a}$ と $U_{C}$ を入力すると, $\mathrm{OP}_{\mathrm{SUB}}$ で $\theta_{R}=\theta_{a}-\theta_{B}$ が算出され, $\mathrm{OP}_{\theta \mathrm{G}}$ で $A \times \theta_{R}$ が演算される. $\theta_{R} \leqq 0$ で $U_{C}$ は減 衰せず, $\theta_{a}$ の補正は不要である. 半波整流部 $\mathrm{H}_{\mathrm{S}}$ を通して, $\theta_{R}>0$ での $U_{C} を$ 分離し, $\mathrm{OP}_{\mathrm{SQ}}$ で $\left(A \times \theta_{R}\right)^{2} \times U_{C}$ の演算を行う. 同時に $\mathrm{OP}_{\mathrm{UG}}$ で $B \times U_{C}, \mathrm{OP}_{\mathrm{ADD}}$ で加算し，式 (4) の演算を完了する.

図 6 に，温度補償及び上記補正を行った時の流速 $U_{R}$ の $U_{0}$ に対する静特性を示寸. $U_{0}=1 \sim 10.5 \mathrm{~m} / \mathrm{s}, \theta_{r} \leqq \theta_{a} \leqq 120^{\circ} \mathrm{C}$ 範囲 で $U_{0}$ と $U_{R}$ の直線性は詋差土 $1 \%$ 未満で較正されており，経験上，従来装置では総計 70 時間程度必要とされた較正所要時 間を，20 時間程度まで大幅に短縮できた.

図 7 に $\theta_{a}=100{ }^{\circ} \mathrm{C}, U_{0}=5.3 \mathrm{~m} / \mathrm{s}$ の流れ場内に円柱（直径 $d=2 \mathrm{~mm}$ ）を設置し，断面中心から流れ方向 $x / d=7$, 高さ方向 $y / d=5$ にIーI 型プローブ(8)を設置して得られた $U_{R}$ と $U_{C}$ の同時僢間波形を示寸. 温度補償と流速補正を併用して得られた流速 $U_{R}$

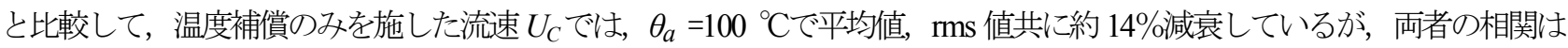
0.999 となり，ほぼ同一波形が得られており，本補正システムの信頼性を示寸.

\section{4. 遅延補償}

\section{$4 \cdot 1$ 新遅延回路}

プローブは，上下流に直径 $d=2.5 \mu \mathrm{m}$ の泠線及び $5 \mu \mathrm{m}$ の熱線を平行に配置した ${ }^{(8)}$. 冷線後流の影響により冷・熱線間距離 は $140 d=0.35 \mathrm{~mm}$ 以上必要とされる ${ }^{(11)}$. 本研究では, 線間距離を $1 \mathrm{~mm}$ に設定した. 凍結仮説 ${ }^{(1)}$ から, 線間距離 $L$, 流速 $U$, 
遅延時間 $\Delta t$ の間には $\Delta t=L U$ の関係が成立し ${ }^{(9)}$ ，流速範囲 $U=1 \sim 12 \mathrm{~m} / \mathrm{s}$ で，遅延時間は $\Delta t=0.083 \mathrm{~ms} \sim 1 \mathrm{~ms}$ となる. 従来の 遅延回路(9) は，1） $\mathrm{A} / \mathrm{D}$ 変換用のコンパレータ,メモリ， $\Delta t$ 短縮用素子が必要であり，メモリ数の仮想的削減の必要上，高 周波域で波形が変形. 2) 温度信号 $\theta(t)=\Theta+\theta^{\prime} の \Theta($ 平均值 $)$ と $\theta^{\prime}$ (変動值)を分離入力し, 出力時に復元するため, 手動によ る览密な調整が必要，等の欠点があった.

図 8 に新遅延回路図を示寸. $M$ は使用メモリのビット数である. 図8 (b) の遅延素子 M50198P は入力部コンパレータや メモリを内蔵し，ノイズが低減され，波形歪みも数 $\mathrm{kHz}$ まで発生しない，スペック上，クロック周波数 $f_{L}=2 \sim 6 \mathrm{MHz}$ は 1 段当たり $\Delta t=0.143 \mathrm{~ms} \sim 0.048 \mathrm{~ms}$ に相当するが，本研究で要求される $\Delta t=1 \mathrm{~ms} \sim 0.083 \mathrm{~ms}$ を上記 $f_{L}$ で実現するため，本素子を 直列に 10 段配置し, スイッチにより切替えて, 流速範用に対応する $N$ 段目から信号を抽出し, 適切な遅延時間 $\Delta t_{N}$ を得た. 検証の結果，上記スペックを上回る $f_{L}(2 \sim 15 \mathrm{MHz})$ まで正確に遅延可能となり，遅延誤差 $3 \mu \mathrm{s}$ 以内では全 10 段で $U=0.75$ $\sim 12 \mathrm{~m} / \mathrm{s}$ に対応する $\Delta t_{N}=1.34 \mathrm{~ms} \sim 0.083 \mathrm{~ms}$ であり，全帯域で波形変形は発生しなかった.

\section{$4 \cdot 2$ 振幅 $\cdot D C$ 電圧自動調整回路}

上記 2）の欠点に対して，図 8 (a) の太線で囲んだ演算回路を入力部に装着し， $\mathrm{OP}_{\mathrm{Zl}}$ と $\mathrm{OP}_{\mathrm{Ol}}$ を用いて入力時の $\theta^{\prime} の$ 最 大振幅を $1 \mathrm{~V}_{\mathrm{P}-\mathrm{P}}$ 以下にした. 自動的に入力スペックが満たされ, 遅延後は出力部の復元回路 $\mathrm{OP}_{\mathrm{Z} 9}$ により元の温度信号に復 元される.

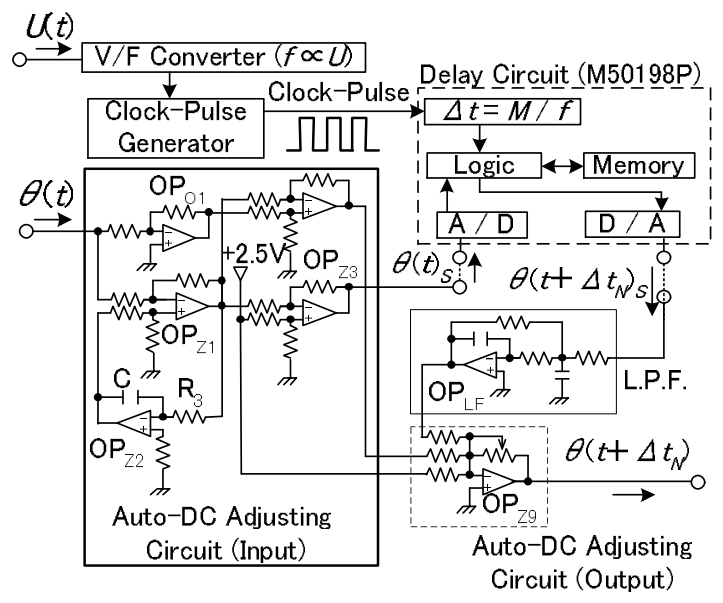

(a)

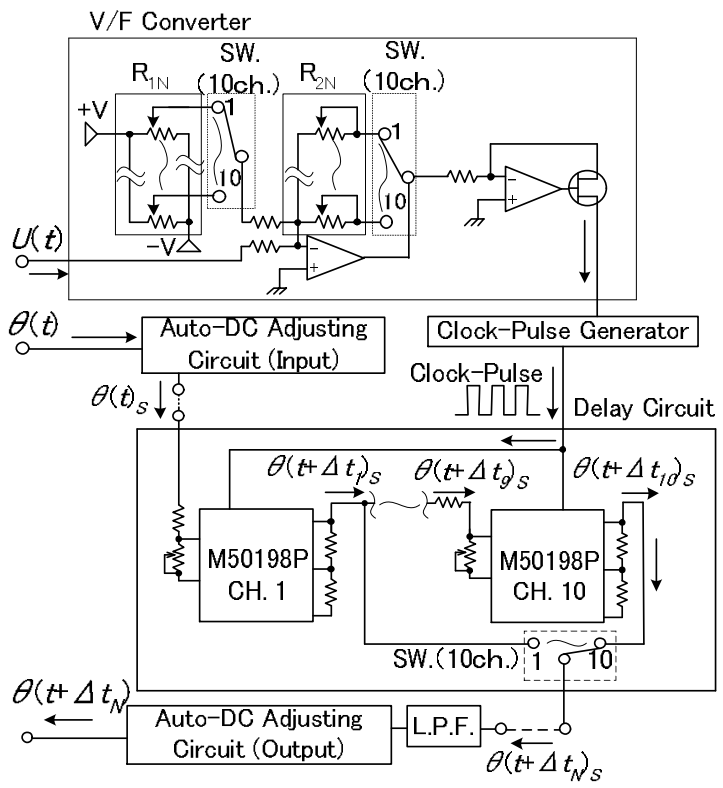

(b)

Fig.8 Delay circuit. (a) Automatic DC adjustor circuit (b) Detailed schematic of the circuit 
$\theta(t)$ は $\mathrm{OP}_{\mathbb{Z}}$ で積分され $\Theta$ となり, $\mathrm{OP}_{\mathrm{Z1}}$ で $\theta(t)$ 一 $\Theta$ としてゼロ補償 ${ }^{(13)}$ される. 次に入力スペックに合わせるため $\mathrm{OP}_{\mathrm{ZZ}}$ で $+2.5 \mathrm{~V}_{\mathrm{DC}}$ が加算され, 素子のスペックを満たす波形 $\theta(t)_{S}$ が得られる. $\theta(t)_{S}$ は, 遅延回路により $\Delta t$ 遅延されて出力さ れるが，入出力間のゲインは厳密に 1 に調整する. 遅延後の温度信号出力 $\theta\left(t+\Delta t_{N}\right)$ は $\mathrm{DC}$ 成分 $2.5 \mathrm{~V}$, 振幅 $1 \mathrm{~V}_{\mathrm{P}-\mathrm{P}}$ 以下に維 持され，ベッセル型ローパスフィルタ $\mathrm{OP}_{\mathrm{LF}}$ で高周波ノイズ成分を除去する. カットオフ周波数 $f_{C}$ を温度信号の上限周波数

(数 $\mathrm{kHz})$ より約 1 桁大きく設定し，位相ずれを $6 \mathrm{deg}$. 以下に抑えた. $\Theta\left(t+\Delta t_{N}\right)$ と $\theta^{\prime}\left(t+\Delta t_{N}\right) s_{S}$ は $\mathrm{OP}_{\mathrm{Zg}}$ にて $\Theta(t)$ と $\theta^{\prime}(t)$ に 一致させる.

\section{$4 \cdot 3$ 遅延時間調整法}

各素子の遅延時間 $\Delta t$ が同一と仮定すると, $N$ 段目の累積遅延時間 $\Delta t_{N}$ は $\Delta t_{N}=\Delta t \times N$ となる. $f_{L}$ と $\Delta t$ は反比例し, 最小・最大流速 $U_{\text {min }} \sim U_{\text {max }}$ 間で $U$ に比例した $f_{\text {Lmin }} \sim f_{L \text { max }}$ を入力寸ることで, $N$ 段目の $\Delta t_{N}=N \times \Delta t_{\text {max }} \sim N \times \Delta t_{\text {min }}$ となる. $N$ 段 目での換算流速を $U_{C N}=L / \Delta t_{N}$ とした時，実流速 $U_{\text {min }} \sim U_{\text {max }}$ と実現可能な最小及び最大值 $\left(U_{C N}\right)_{\text {min }} \sim\left(U_{C N}\right)_{\text {max }}$ とが一致するよう にクロック周波数を調整すれば, $N$ 段目での正確な遅延を実現できる.

例として $N=8$ の場合, 図 8 (b) で 8 段目用の半固定抵抗 $\mathrm{R}_{1 N(N=8)}$ で加算 $\mathrm{DC}$ 電圧を $0 \mathrm{~V}$ とし, $\mathrm{R}_{2 N(N=8)}$ でゲイン を 1 に設定することで $U=1 \sim 6 \mathrm{~m} / \mathrm{s}$ に対し $f_{L}=1 \sim 6 \mathrm{MHz}$ のクロックが発生される. Uに対する $f_{L}$ が正確でないため, 図 9 に示寸ように, $\Delta t_{8 \max } \sim \Delta t_{8 \min }$ から得られた換算流速 $\left(U_{C 8}\right)_{\text {min }}=1 \mathrm{~m} / \mathrm{s} \sim\left(U_{C 8}\right)_{\max }=3 \mathrm{~m} / \mathrm{s}$ の值と実流速 $U(1 \sim 6 \mathrm{~m} / \mathrm{s})$ は 一致しない. よって $U$ と $U_{C 8}$ 間に最小二乗法を適用し,

$$
U=0.0303+2.028 U_{C 8}=2.028 \times\left(0.0149+U_{C 8}\right)
$$

を得た. $\mathrm{R}_{\mathrm{IN}(N=8)}$ で加算 $\mathrm{DC}$ 電圧を $0.0149 \mathrm{~V}$ に, $\mathrm{R}_{2 N(N-8)}$ でゲインを 2.028 と再設定することにより, 調整した. 図 9 に示 すように，8段目における $U=1 \sim 6 \mathrm{~m} / \mathrm{s}$ の範囲内で $f_{L}=2 \sim 15 \mathrm{MHz}$ となり，Uと $U_{C B}$ の值が一致し，線形性が確保された.

本回路は各素子の遅延時間の累計で $\Delta t$ を実現しており，出力段が違えば同一Uでも $\Delta t$ が異なる，更に，同一 $f_{L} に$ 対す る各素子の遅延性能には無視し得ないばらつきがあり，そのままでは $\Delta t$ の線形性が確保されない，そのため, スイッチで 切替え可能な各段専用のクロック設定回路を設置し，全段に対して個別に調整を行う.

流れ場により $\Delta t$ の許容可能誤差は異なるが，最高精度時の3 $\mu \mathrm{s}$ および実用上支障がない $80 \mu \mathrm{s}$ 以内とした場合の有效流 速範囲を図 9 に示寸，平均流速に合わせて出力段を切り替えることにより，誤差 $80 \mu \mathrm{s}$ 時でも最大で $0.4 \sim 12 \mathrm{~m} / \mathrm{s}$ の範井で正

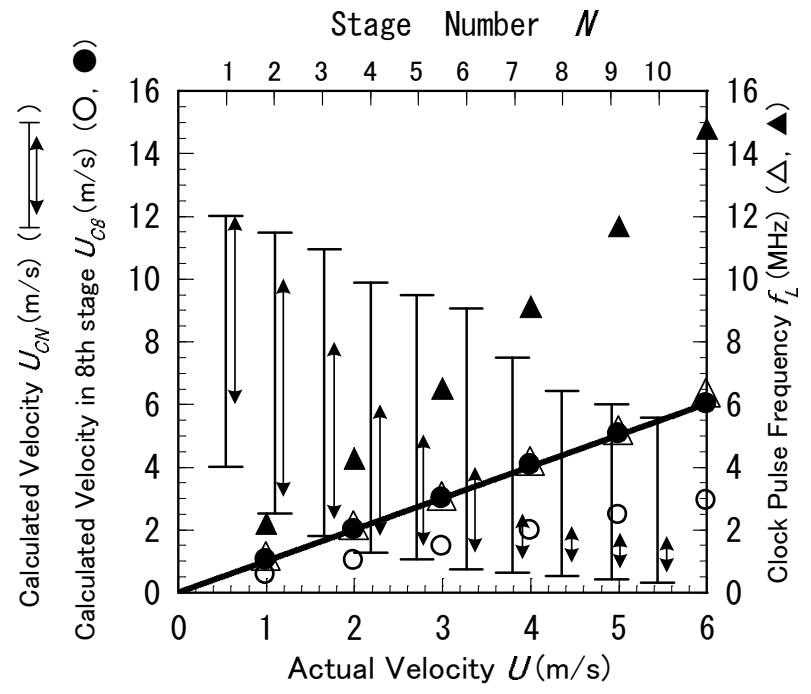

Fig.9 Relation between $U_{C 8}$, calculated from $\Delta t_{8}$, clock pulse frequency, and the actual flow velocity at the 8th stage. Effective $U_{C N}$ range in each stage.

$\triangle, \bigcirc$ : Before adjustment. $\boldsymbol{\Delta}, \mathbf{O}$ :After adjusted by variable resistors.

Effective $U_{C N}$ range ; $\longleftrightarrow$ : error $\leqq 3 \mu \mathrm{s}, \longmapsto \mid$ : error $\leqq 80 \mu \mathrm{s}$ 


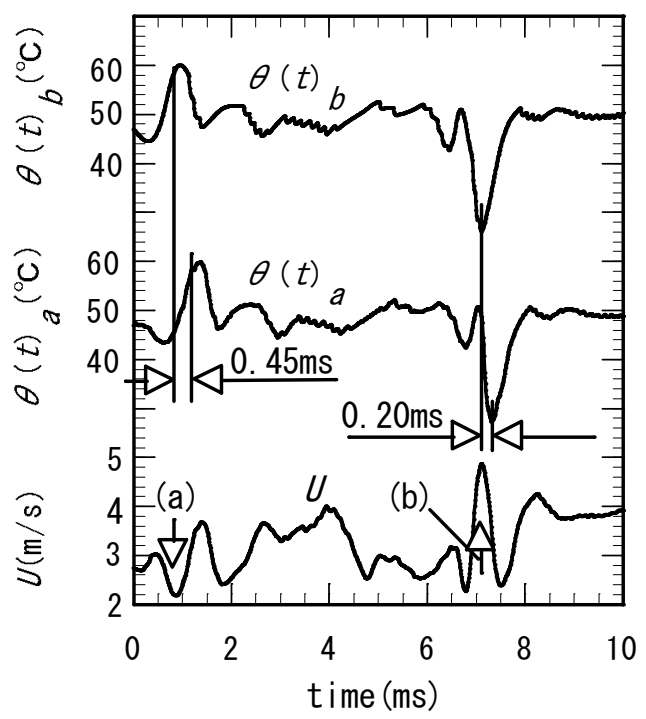

Fig.10 Comparison among the time traces of $\theta_{a}, \theta_{b}, U$ between before and after delay in the 8 th stage.

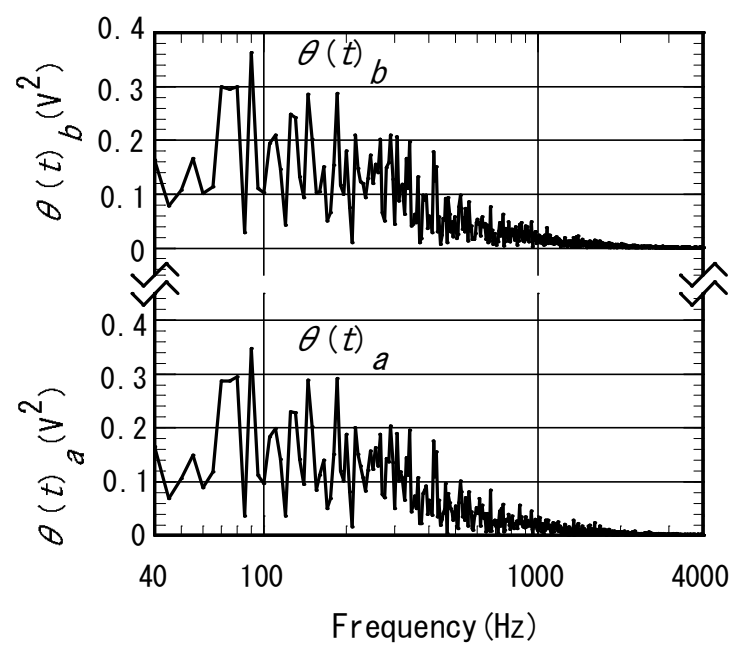

Fig.11 Comparison of the power spectra of $\theta_{a}, \theta_{b}$ between before and after delay in the 8 th stage.

確な遅延が可能となった.

\section{$4 \cdot 4$ 遅延部測定結果}

図 10, 11 に一様流速 $U_{\sigma}=3.0 \mathrm{~m} / \mathrm{s}$, 室温との温度差 $\Delta \theta=50^{\circ} \mathrm{C}$ の加熱自由噴流内 $x / h=1, y / 0.5 h=+1$ において I- $\mathrm{I}$ 型 プローブ(8) にて温度・流速を計測した瞬間波形, 及びパワースペクトルを示す. $h$ は出口矩形断面の一辺 $60 \mathrm{~mm}$ である. 図 10 では，遅延前の信号 $\theta(t)_{b}$ に対し，遅延後の 8 段目からの出力温度信号 $\theta(t)_{a}$ が同一波形を維持した まま，(a) 瞬間流速 $U=2.2 \mathrm{~m} / \mathrm{s}$ 時に $\Delta t=0.45 \mathrm{ms，(b)} U=4.9 \mathrm{~m} / \mathrm{s}$ 時に $\Delta t=0.20 \mathrm{~ms}$ だけ正確に遅延されている.

図 11 には, $4 \mathrm{kHz}$ 程度まで $\theta(t)_{b}$ と $\theta(t)_{a}$ のパワースペクトル分布がよく一致していることが示されている. $6 \mathrm{kHz}$ 以上でノイズや位相遅れの影響が現れ始めるが，対象とする温度信号の上限周波数は $5 \mathrm{kHz}$ 程度と寸れば，本回 路は十分な性能を有していると言える.

更に, $U_{0}=5.0 \mathrm{~m} / \mathrm{s}$ の気流中, $\Delta \theta=140^{\circ} \mathrm{C}$ の一様な表面温度分布を持つ直径 $d=30 \mathrm{~mm}$ の加熱円柱を水平に置き，そ の後流内, $x / d=3, y / d=+0.17$ において同時計測した温度 $\theta$ と $x, y$ 方向流速 $U_{h}, V_{h}$ 及び，同位置で通常の熱線流速 計（無補償）を使って得られた非加熱円柱後流の $x, y$ 方向流速 $U_{n h}, V_{n h}$ を比較した. 


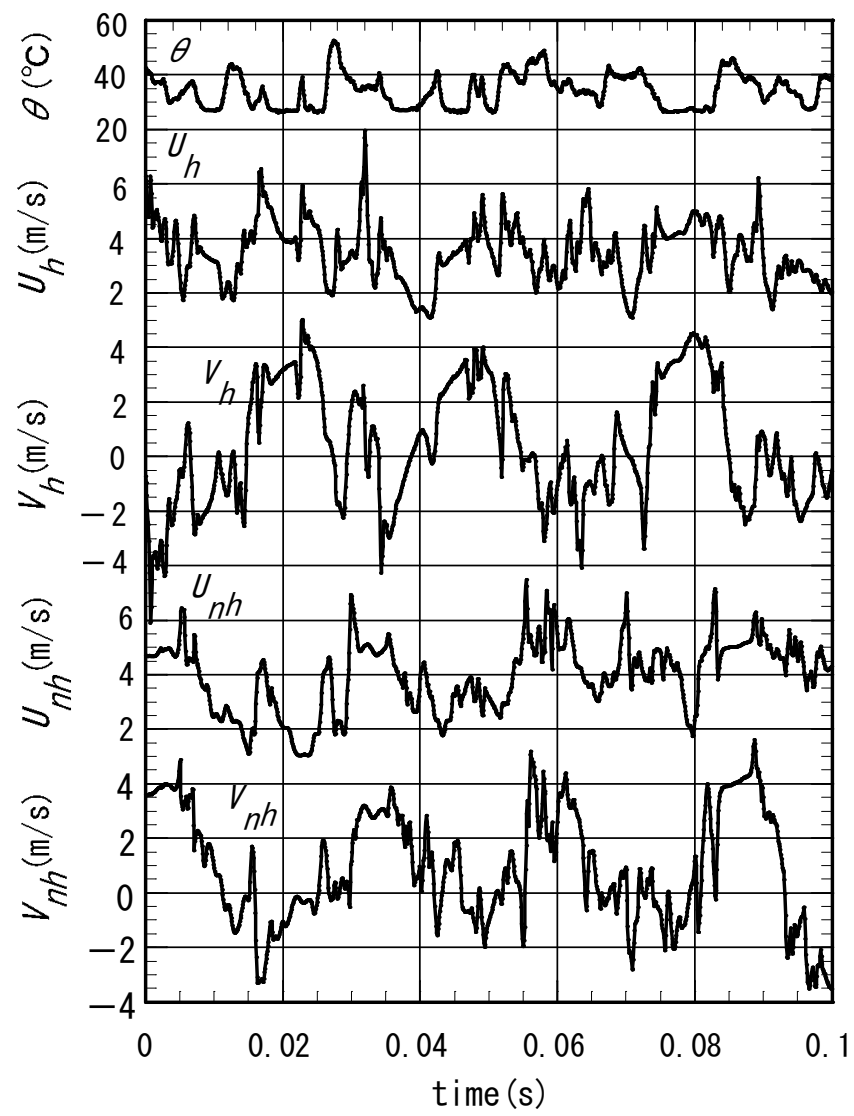

Fig.12 Comparison among the time traces of temperature and velocity fluctuations behind a heated and a non-heated cylinder wake.

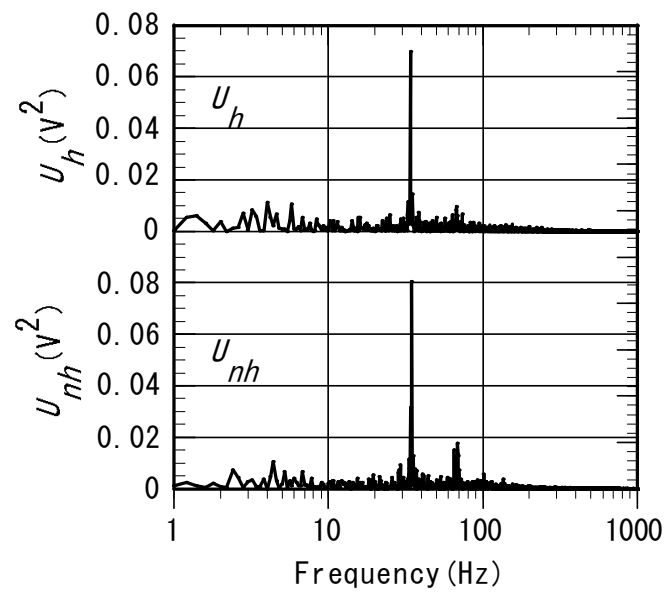

Fig.13 Comparison between the power spectra of the velocity fluctuations for a heated and an unheated cylinder wake.

図 12 の瞬間波形では $\theta$ が $\Delta \theta=20^{\circ} \mathrm{C}$ 程度の範囲で変動しているが, $U_{h}$ と $U_{n h}, V_{h}$ と $V_{n h}$ は平均流速, 変動強度等 により, 統計的にほぼ一致している. 図 13 に $U_{h}$ と $U_{n h}$ のパワースペクトルを示す. 各周波数で両者の分布はほぼ 一致している.ここには図示しないが， $V_{h}$ と $V_{n h}$ のパワースペクトルもほぼ一致すること， $U_{0}=5.0 \mathrm{~m} / \mathrm{s}$ の気流中， 各種 $\Delta \theta$ に設定した加熱・非加熱円柱後流内の本計測位置においては，高次相関量を除き上記パラメータに本質的 な違いが生じないことを確認している. 即ち, 渦発生周波数も含め, 加熱・非加熱状態での両者の波形は統計的 に充分に一致し, 本補償法の有効性が明確となった。 以上の結果は, 温度流速場の計測で厳密な高次相関量を得 ることを可能にすると考えている. 


\section{5. 結}

言

熱流体に関する正確な高次相関量の導出を目的とした温度流速計の高精度化を試み，以下の結論を得た。

1.より厳密な温度補償式に基づく回路を試作し，流速に対して高精度な温度補償が可能となった。

2. 簡単な調整で, 室温 $\theta_{r}$ 気流温度 $\theta_{a} \leqq 120^{\circ} \mathrm{C}$ 範囲で速度信号が誤差士 $1 \%$ 以内に収まり, 波形が変形・減衰しない流速 補正回路を開発し，回路各部分の調整が簡略化した.

3. 高いサンプリング周波数を持つ素子を採用し，振幅・DC 電圧自動調整回路を試作して遅延補償部の調整を自動化した 結果, 約 $6 \mathrm{kHz}$ まで出力信号波形の変形が観察されなかった.

4. 大幅こ較正時間を短縮できた.

\section{文献}

(1) 星野茎史, 沢田照夫, “急変するガス温度と流速の測定法の研究”, 日本機械学会論文集(第 2 部), Vol. 38, No. 305 (1972), pp. 139-147.

(2) Sakao, F., "Constant temperature hot wires for determining velocity fluctuations in an air flow accompanied by temperature fluctuations”, Journal of Physics E: Science Instruments, Vol. 6 (1973), pp. 913-916.

(3) 菱田幹雄, 長野靖尚, 田代真一郎, “速度変動と温度変動の同時測定”, 日本機械学会論文集(第 2 部), Vol. 43, No. 365 (1977), pp. 225-232.

(4) Fabris, G., "Probes and method for simultaneous measurements of true instantaneous temperature and three velocity components in turbulent flow", Review of Scientific Instruments, Vol. 49, No. 5 (1978), pp. 654-664.

(5) Chevray, R.C. and Tutu, N.K., "Simultaneous Measurements of Temperature and Velocity in Heated FLows", Review of Scientific Instruments, Vol. 43, No. 10 (1972), pp. 654-664.

(6) Maye, J.P., "Error Due to Thermal Conduction Between the Sensing Wire and Its Supports when Measuring Temperatures With a Wire Anemometer Used as Resistance Theromometer", DISA Information, No. 9 (1970), pp. $22-26$.

(7) Hojstrup, J., Rasmussen, K. and Larsen, S.E., "Dynamic Calibration of Temperature Wires in Still Air”, DISA Information, No. 20 (1976), pp. 22-30.

（8）蒔田秀治，森重樹，澤田耕二，“温度流速計の高精度化(第 1 報，システム構成及び温度計の高周波位相補償回 路)”，日本機械学会論文集 B 編，Vol. 58, No. 545 (1992), pp. 90-97.

（9）蒔田秀治，森重樹，澤田耕二，“温度流速計の高精度化(第 2 報，温度計の低周波位相補償回路および空間分解能 の向上について)”，日本機械学会論文集 B 編，Vol. 58, No. 554 (1992), pp. 3100-3107.

（10）国立天文台編，理科年表，（2001），p. 482，丸善.

(11) Hishida, M. and Nagano, Y., "Simultaneous measurements of velocity and temperature in nonisothermal flows", Transactions of ASME, Journal of Heat Transfer, Vol. 100 (1978), pp. 340-345.

(12) Taylor, G.I., "The spectrum of turbulence", Proceeding of the Royal Society of London, series A164 (1938), pp. 476-490.

(13)トランジスタ技術 SPECIAL， No. 17 （1987），p. 105，CQ 出版社. 